\title{
The Effects of Gamma Radiation in Nectar of Kiwifruit (Actinidia deliciosa)
}

\author{
Marcia N. C. Harder ${ }^{1}$ and Valter Arthur ${ }^{2}$ \\ ${ }^{1}$ Institute of Energetic and Nuclear Research - IPEN/CNEN/USP \\ Technology College of Piracicaba - FATEC Piracicaba \\ ${ }^{2}$ Center of Nuclear Energy in Agriculture, University of Sao Paulo - CENA/USP
}

Brazil

\section{Introduction}

\subsection{The kiwifruit}

The kiwifruit (Actinidia deliciosa) is an exotic fruit to Brazil belonging to the family Actinidiaceae, the genus Actinidia, which has some edible species such as A. chinensis, A. arguta, A. kolomikta, A. polygama and A. eriantha and contrary what of imagines whose origin center are the China mountainous regions which have from 800 to $2000 \mathrm{~m}$ altitude, where it grows in the forest shade and where it was called the Chinese gooseberry. Also found were records of the presence of kiwi to the northeast of India and Japan. New Zealand has always taken this credit but the first productions of the A. delicious species appeared only in mid 1910 and definitely where it was named in honor of the bird symbol of this country due to his likeness and that receives the same name: Kiwi.

The kiwifruit is a plant belonging to the order Theales, Actinidiaceae family and genus Actinidia with more than 53 species including the Actinidia deliciosa is the most important (Ferri, Kersten, Machado, 1996).

The genus Actinidia in 1959 has been classified by Wallich. Hutichon that divided the family into genera actinideácea only climbers: Actinidia, Clamatochetra and Sladenita (Almeida, 1996).

They are typical plants of locations with temperate or subtropical mountain. The varieties of fruit most widely marketed varieties are produced by several species of Actinidia deliciosa and to a much lesser extent, by some varieties of Actinidia chinensis. The fruit pulp has coloration ranging from bright green to yellow, with several small seeds and black in the middle and characterized by the oval form and to be flattened. The bark has a light brown color covered with small fells. Being a low-calorie fruit is widely used in energy-restricted diets because about $90 \%$ of its weight consists of water (Demczuk Junior, 2007; Oliveira, 2011).

Another feature of the kiwifruit plant is to be clambering and its production be conducted preferably in tutoring systems (Figure 1) as the vines in order that the fruits do not touch the ground preserving them of the early deterioration. 


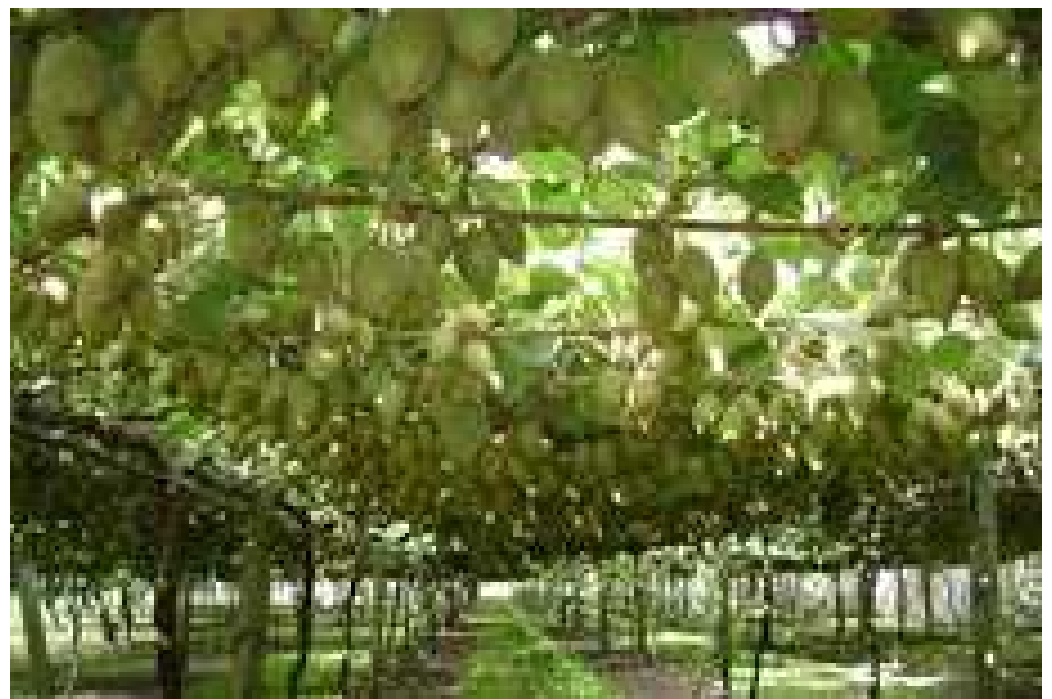

Fig. 1. Kiwifruit tutored system plantation (SEMAPI, 2011)

The species of Actinidia deliciosa (A. Chev.) several delicious varieties are known to be preferred by the consumer and therefore more widespread the variety 'Hayward' (Figure 2) fruit with better taste and aroma (flavor) and a greater capacity for storage.
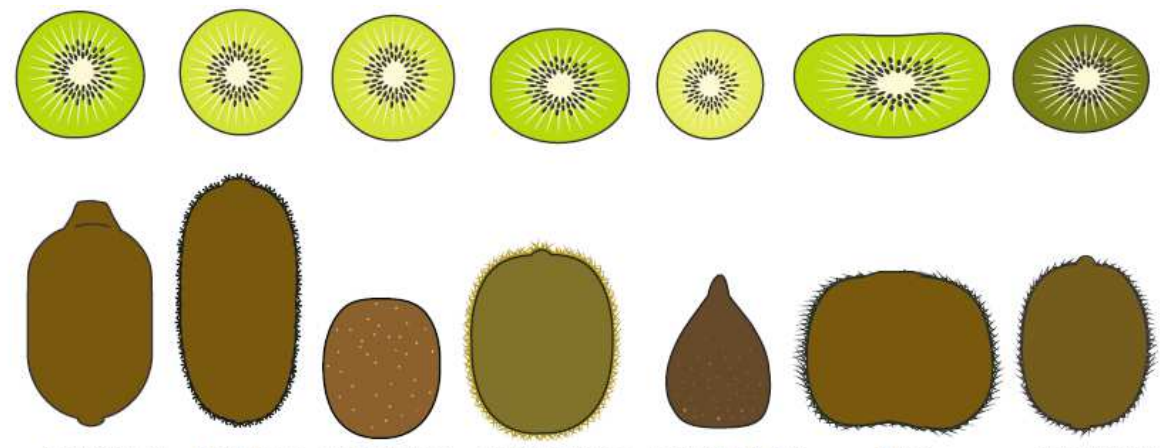

ABBOTT

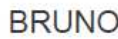

GOLDEN

HAYWARD KAKIHARA

MG

MONTY

Fig. 2. Kiwifruit varieties (CEAGESP, 2011)

\subsubsection{Kiwifruit cultivars}

Also like all other fruits the kiwifruit has many cultivars, which differ in pollinator (male) and producing (female) and the adaptation to the environmental conditions; harvest time; chances of post-harvest conservation; productivity; format; size; taste; resistance to pests and diseases; among others (Souza; Marodin; Barradas, 1996).

Oliveira (2011) shows which varieties are part of the division between male and female cultivars: 


\subsubsection{Female cultivars}

a. Abbot

It is a vigorous plant; very productive; early flowering; with flowers grouped about two or three. The flowers are creamy white and the petals have rounded elliptical, with the edges slightly wrinkled. The leaves are usually short and round with pointed apex (ALMEIDA, 1996).

The fruit has an oblong shape; weighing 65 to 70 grams; with a period of maturation medium; good storage under refrigeration and successfully supporting the handling and transport. The pulp is bright green color; fragrant; mildly acidic; considered as has a good quality and very popular in New Zealand for family consumption. It features low demand hours in the cold and high bud fertility and therefore a high productive power can be 400 kilograms of fruit per foot (Souza; Marodin; Barradas, 1996).

b. Bruno

It is a vigorous and productive plant. Have solitary flowers (rarely combined) with creamwhite elliptical petals; more or less rounded and flat. The leaves have circular shape with the bottom rope. The fruits are medium in size - 60 to 70 grams - very uniform; cylindrical in shape and elongated; bark brown and covered with dense fell, short and spiky (Almeida, 1996).

The pulp is sweet and a little tart, very goodly, with the highest concentration of vitamin C than other varieties. The maturity is very early with the possible preservation in a refrigerator however had a reduced resistant to handling and transportation. In southern Brazil, the harvest usually occurs in April opening. It is not very demanding in cold times requiring a half hours of cold necessary to cultivate Hayward. In the conditions of the Brazil Southern the Bruno cultivar has shown the best yield among the varieties grown kiwifruit tree (Souza; Marodin; Barradas, 1996).

c. Hayward

Presents late-flowering with slightly lower productivity for other varieties of flowering coincide. Its flowers are solitary and rarely in pairs. It is very sensitive to chlorosis; drought and nematodes. Has multiplication by cutting easier than the others (Souza; Marodin; Barradas, 1996).

It is a plant with medium vigor. It has the harvest beginning around the first half of November. At harvest the fruit must reach a level of maturity as measured by the method of soluble solids of at least 6.2 percent. The fruits are heavy (90 to 150g); oval with the elliptical cross section; with brown bark greenish; covered with fine fells (Almeida, 1996).

The leaves are rounded and the base strings with overlapping. The pulp is green with hints of straw-colored; moderately juicy; slightly tart and mildly fragrant and aromatic with good taste qualities (Almeida, 1996). According to Souza, Marodin and Barradas (1996), the perfect balance between acids and sugars that make the variety is preferred by markets around the world.

Have good resistance to transportation; handling and excellent cold storage. Although not determined it is estimated that this growing need 700 to 1,000 hours of temperatures below $7.2^{\circ} \mathrm{C}$ during winter (Souza; Marodin; Barradas, 1996). 
This cultivar is now widely cultivated in the world due to its excellent features and the fact that the packaging and the alveoli are thought to their fruits.

\section{d. Monty}

It is a very vigorous plant and induces major productions. The flowers are cream-white with variable petals form and grouped into two or three branches. The leaves are usually roundbased trunk (Almeida, 1996).

The fruits are elliptical medium size and uneven with average weight of $65 \mathrm{~g}$ but in some places is around $40 \mathrm{~g}$. Maturation takes place in mid-season and the fruits are difficult to preserve. They are little resistant to transport and handling. Its flesh is bright green, sweettart and fragrant (Souza; Marodin; Barradas, 1996).

\subsubsection{Male cultivars}

\section{a. Matua}

It is an early flowering cultivar by abundant; prolific and persistent form for a long time. Its flowers are grouped in variable number from 1 to 5 . In some situations presents an early flowering in relation to 'Hayward'. Features of a high-pollen than the 'Tomur' variety (Souza; Marodin; Barradas, 1996).

\section{b. Tomur}

It is a plant variety which starts blooming in mid-season and lasts a long time. The flowers are grouped in varying levels from 1 to 7 usually 5. It blooms a little later than 'Matua' and seems especially suited to pollinate 'Hayward'. Its pollen has a low germination (Souza; Marodin; Barradas, 1996).

\subsubsection{World production}

There are few data about the world production which is known is that today in the worldwide the main producer of kiwifruits are Italy; China; New Zealand and Chile (Figure 3).

Kiwifruits can be found throughout the year because there is a mismatch between the different harvest times for each producing country: since mid-May until late November in New Zealand; and the rest of the time in the Mediterranean countries; Chile; California and Australia. It is a product that was developed commercially in recent years through to a marketing job done by New Zealand which is an example of how to disclose a 'new product'.

\subsubsection{The fruit characteristics}

Kiwi fruits display tolerance to low temperatures for conservation, allowing storage for up to 8 months under these conditions (Schuck, 1992).

Kiwi is one of the only fruits which does not have a specific regulation from the Brazilian Ministry of Agriculture about standardization and classification. Therefore, there is no official rules for commercialization, classification, selection and packing for kiwi in Brazil (Harder et al., 2009). 
Kiwi: U.S. import-eligible countries; world production and exports

\begin{tabular}{|c|c|c|c|}
\hline Country $1 /$ & Production & Total exports & Export value \\
\hline & \multicolumn{2}{|c|}{1,000 metric tons } & 1,000 US $\$$ \\
\hline Argentina & nd & 0,41 & 213,00 \\
\hline Australia & 5,35 & 0,50 & 842,00 \\
\hline Canada & 0,08 & 0,07 & 125,00 \\
\hline Chile & 170,00 & 160,19 & $143.053,00$ \\
\hline France & 70,16 & 26,84 & $50.776,00$ \\
\hline Greece & 70,10 & 36,79 & $34.356,00$ \\
\hline Italy & 417,00 & 333,97 & $389.450,00$ \\
\hline Japan & 32,80 & 0,01 & 37,00 \\
\hline Korea, Republic of & 10,50 & 0.00 & 0.00 \\
\hline New Zeal and & 365,00 & 347,92 & $573.490,00$ \\
\hline Spain & 13,00 & 9,71 & $13.753,00$ \\
\hline Percent el igible & 94,87 & 82,02 & 77,30 \\
\hline World median & 11,40 & 0,01 & 8,00 \\
\hline World average & 56,38 & 11,54 & $16.000,94$ \\
\hline
\end{tabular}

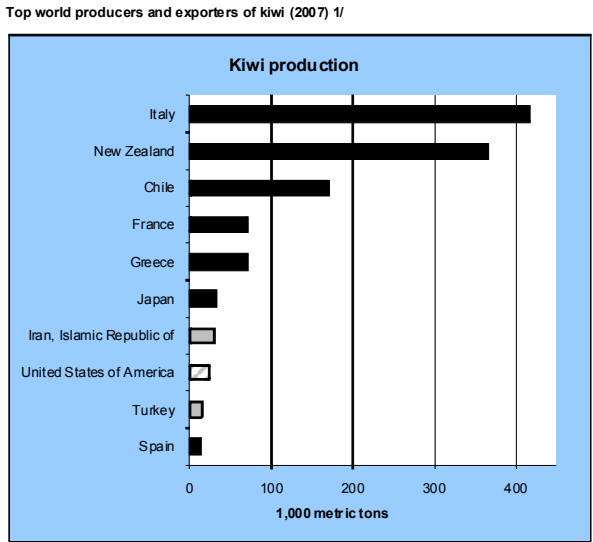

Note: $n d=$ no data; Percent eigible $=$ Percentage of total world production, export, or export value for this commodity for countries eligible to export this commodity to the United States according to frut and
vegetable import regulations from USDA's Animal and Plant Health Inspection Service (APHIS). Median = Median global production quantity, export quantity, or value. Median is the value for which half of all values in a senies are greater and half are smaller. Average $=$ Average global production quantity, export quantity, or value. Average is the sum of all numbers in a series divided by the total number of entries in that series.

1/ Countries eligible to export this commodity to the United States according to APHIS regulations as of June 2010. See Documentation for more information. Countries in bold are high-income nations, all others are middle- and low-income nations according to the 2010 country classification developed by World Bank.

* Only certain region(s) within this country is (are) eligible to export this commodity to the United States or is (are) regulated differently than the rest of the

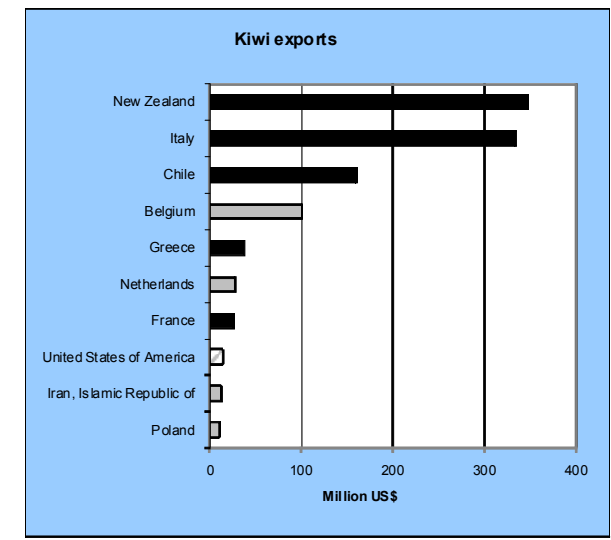

Fig. 3. Kiwi world production and exports (USDA, 2011)

The kiwi fruit presents a high nutritional value, rich mainly in vitamin $C$ and fibers, calcium, iron and phosphorus, which turns it an excellent nutritional option, with an important association between quality attributes and flavor, with great acceptance in consuming markets, mainly among children. Kiwi contains an enzyme actinine with meat softening properties by the reason it can be used to soften the meat before cooking and reduce the cooking time and addition flavor with the fruit pulp. Furthermore the actinidina prevents the coagulation of gelatin and is responsible for the bitter taste that dairy products are consumed when presented with kiwi fruit. (Carvalho, 2000).

One of the fibers is found in kiwi fruit pectin that helps lower blood cholesterol levels. Other bioactive compounds found in kiwifruit are phenolic flavonoids, amino acids such as arginine and glutamate and chlorophyll. All compounds of the kiwi provide a potential anticancer and anti-inflammatory that helps in increasing the immunity of individuals who have the habit on the frequency of fruit intake. 
The nutritional composition of kiwifruit per 100 grams of fruit is the following: 67 calories; carbohydrates $15 \mathrm{~g}$; $1 \mathrm{~g}$ of protein; $0.5 \mathrm{~g}$ of lipid; $1 \mathrm{~g}$ of fiber; $17 \mathrm{~g}$ of Vitamin A; Vitamin C 80$300 \mathrm{mg}$; $0.4 \mathrm{~g}$ of iron; calcium $26 \mathrm{~g}$; sodium $5.2 \mathrm{~g}$; $30 \mathrm{~g}$ of magnesium; potassium $280-340 \mathrm{~g}$ and phosphorus 20-40g.

A recent study published by Chang et al. (2010) reveals that the kiwifruit is excellent for improves bowel function in patients with irritable bowel syndrome with constipation (IBS), characterized by preexisting functional diarrhea, ranging from normal functioning of the intestine and constipation.

\subsection{Food irradiation}

Irradiation is an excellent method of food conservation, as well as reinforces the action of other applied processes for the same purpose. Irradiation satisfies completely the objectives of giving food nutritional stability, sanitary conditions and a long shelf life (EMBRARAD, 2007).

The Brazilian law follows the international recommendations suggested by the Food and Agriculture Organization (FAO); International Atomic Energy Agency (IAEA) and Codex Alimentarium (UN). Currently all standards for the use of this technology are described in Resolution No. 21. That according to this any food can be irradiated subject to compliance with the minimum and maximum dosage applied where the minimum dose should be enough to achieve the intended purpose and the maximum must to be less than that which would compromise the functional properties and/or sensory attributes of food (Oliveira, 2011; Oliveira et. al 2011 and Modolo; Silva; Arthur, 2011).

According to the same author, food irradiation has been the subject of intense research for over forty years. International organizations such as the Food and Agriculture Organization (FAO) and World Health Organization (WHO) has been reviewed all researches about this theme and concluded that irradiated food is safe and beneficial (Ornellas; Gonçalves; Silva; Martins, 2006). Similarly, the nutritional value of irradiated foods was compared with other food processing methods, with favorable results showing that the irradiation uses are the same with common treatments or better.

Treatment of fresh fruit by irradiation is performed with the primary purpose of delaying the process of ripening and decay resulting in a significant increase in shelf life of irradiated fruit. On the existence of many studies are still needed further research on the appropriate doses and the effects of radiation on the qualities of the fruit. Therefore, the application of radiation associated with cold storage can keep the quality attributes of kiwifruit adding value to cultivate (Levite; Santos; Foes, 2008).

Investigations demonstrated that macronutrients, such as proteins and carbohydrates are relatively stable at doses of up to $10 \mathrm{kGy}$, and that micronutrients, mainly vitamins can be sensitive to any method of food conservation. The sensitivity of various types of vitamins to irradiation and other methods for food conservation is variable; vitamin C and B1 (thiamin) are the most sensitive to irradiation. In general, the process of irradiation with acceptable dose cause little chemical changes in foods, whereas the food nutritional quality is no more affected than when it is treated with other conventional methods of preservation (Villavicencio et. al., 1998; Wiendl 1997). 
In the contemporary environment people have requested more time to work and less time to make a good meal so read-to-eat food became a practical way for a more balanced meal. The minimally processed foods are a reality and a perfectly viable option.

The use of minimally processed products in Brazil began in the 90s by some companies attracted by the new market trend. The success of this undertaking depends however by the use of raw materials of high quality; handled and processed with high hygienic condition. It is necessary to use appropriate packaging and temperature control in the processing; distribution and marketing since they are critical to the reduction of physiological deterioration and/or microbiological (Leite; Gêa; Arthur, 2006).

The use of radiation to control microbial contamination in ready-to-eat foods becomes perfectly satisfactory from the point of view of health ensuring food safety for consumption as the technological point of view because several studies have shown that the radiation does not interfere or interfere not significantly in the quality of some foods that was submitted of this process of conservation.

Furthermore of this kind of technology is considered "cold" and has almost no influence on sensory parameters, including the item texture.

\subsection{Food irradiation in kiwifruit}

Oliveira (2011) in a study with Kiwifruits minimally processed and irradiated at doses of 0 (control), 1 and $2 \mathrm{kGy}$ and stored under refrigeration at $6^{\circ} \mathrm{C}$ found the following considerations:

- No significant difference between the doses for the parameters $\mathrm{pH}$, chlorophyll and acidity;

- Mass loss decreased with increasing dose and storage period;

- The soluble solids content showed a significant difference between treatments, the results of the samples during analysis showed variation probably due to lack of homogeneity of the samples on the period of maturation;

- A reduction in ascorbic acid content in the treatments and during the storage period;

- The humidity and acidity did not differ between treatments and periods of analysis;

- Therefore gamma radiation did not induce harmful changes in physical-chemical properties of the kiwifruit which can be used for the preservation of minimally processed kiwifruit.

\subsection{Nectar}

Still about the context of ready-to-eat food a good option is the use of technological concepts for the production of juices. It is an alternative fast; easy and enjoyable for take fruit.

Nectar is a sweet drink non-alcoholic and non-fermented base of fruit juice in which the concentration of the pulp is at least 20 to $30 \%$ depending of the fruit.

The fruit is valued for the health benefits and contribution to improving the quality of life. The need for convenient products for the consumer market brought about the emergence of fast food chains leading consumer foods low in fiber; vitamins and minerals; rich in salt value; fat and sugar. A reflection of these eating habits was apparent by the increasing 
incidence of obesity and cardiovascular disease. Today consumers already have access to food at the same time convenient and healthy. The light processing adds to the fruit (products healthy by nature) the value of convenience. With the advancement of technology it is possible to find in the market peeled and sliced fruit or juice form with cool features ready for consumption (Demczuk Junior, 2007; Oliveira, 2011; Oliveira et. al., 2011).

The principal processed products obtained from fruits are juices and nectars (sweetened drink). In this work, a no-alcoholic sweetened drink was prepared from Kiwi, containing $50 \%$ pure juice and sugar, and ready to consume (Tocchini, 1995), which was treated with irradiation at $0.5 ; 1.0$ and $2.0 \mathrm{kGy}$ doses.

The aim of this work was to formulate a no-alcoholic sweetened drink, starting from kiwi fruits and to submit the drink to gamma radiation derived from a source of Cobalt-60, and evaluates changes in physical and chemical quality attributes cause by irradiation.

\section{Material and methods}

Kiwi fruits (Actinidia deliciosa) in natura were locally purchased. The fruits were washed in a bleach solution, peeled, and cut in half. The juice was extracted by home centrifuge Walita, pre-filtered, centrifuged at $5000 \mathrm{rpm}$, and filtered. Mineral water was added to $50 \%$ volume, and sucrose to reach $16^{\circ}$ Brix. It was made an ultra filtration with ceramic membrane of $0.10 \mu \mathrm{m}$ at the pressure of $3 \mathrm{bar}$ at $45^{\circ} \mathrm{C}$ for clarification, according to Lopes et al. (2005). The drink was kept in $500 \mathrm{~mL}$ plastic bottles (PET), and exposed to the following treatments:

1. Control;

2. Irradiation with $0.5 \mathrm{kGy}$;

3. Irradiation with1.0 kGy

4. Irradiation with $2.0 \mathrm{kGy}$

Irradiation was conducted in a Cobalt-60 source; model Gammabeam 650, of Nordion Canada, installed in the Center of Nuclear Energy in Agriculture of the University of Sao Paulo - CENA/USP., Piracicaba city, State of São Paulo, Brazil. The dose rate was 0.712 $\mathrm{kGy} /$ hour. The analyses were conduced in the Laboratory of Radiobiology and Environment of CENA/USP.

Dosimetry was performed using $5 \mathrm{~mm}$ diameter alanine dosimeters (Bruker Instruments, Rheinstetten, Germany), and the free radical signal was measured with Bruker EMS 104 EPR Analyzer. The actual dose was within 0.02 of the target dose. Samples was turned 360 continuously during the irradiation process to achieve uniform target doses and the nonirradiated control was placed outside the irradiation chamber to have the same environmental temperature effect with the irradiating sample.

\subsection{Physico-chemical analyses}

\subsection{Soluble solids content}

Estimated in refractometer RT-30ATC and expressed n Brix, according to AOAC (1995). 


\subsection{Title acidity}

Determined and estimated as the volume in $\mathrm{mL}$ of $\mathrm{NaOH}$ require to titrate $100 \mathrm{~mL}$ of drink to reach $\mathrm{pH} 8,2$, expressed in percent of citric acid, with the drink diluted 1:10, according to AOAC (1995)

\section{$2.4 \mathrm{pH}$}

Determined using pHmeter MB-10, according to AOAC (1995).

\subsection{Total ascorbic acid}

Determined according to Jacobs (1985) using oxalic acid and titrating with a dichlorobenzeneindophenol solution. Estimated based on volume in $\mathrm{mL}$ of the the solution of 2,6 dichlophenolindophenol used to titrate $50 \mathrm{~mL}$ of drink, until becoming light pink, expressed in $\mathrm{mg}$ ascorbic acid/100mL kiwi drink.

\subsection{Color}

The colorimeter Minolta CR-200 b was used, previously calibrated in White according to pre-determined standards, according to (Bible and Singha, 1993).

Three values of chroma were evaluated: $a^{*}, b^{*}$ and L (Figure 4$)$. The value $a^{*}$ characterizes the color from the red $\left(+a^{*}\right)$ to the green $\left(-a^{*}\right)$; the value $b^{*}$ indicates the color from the

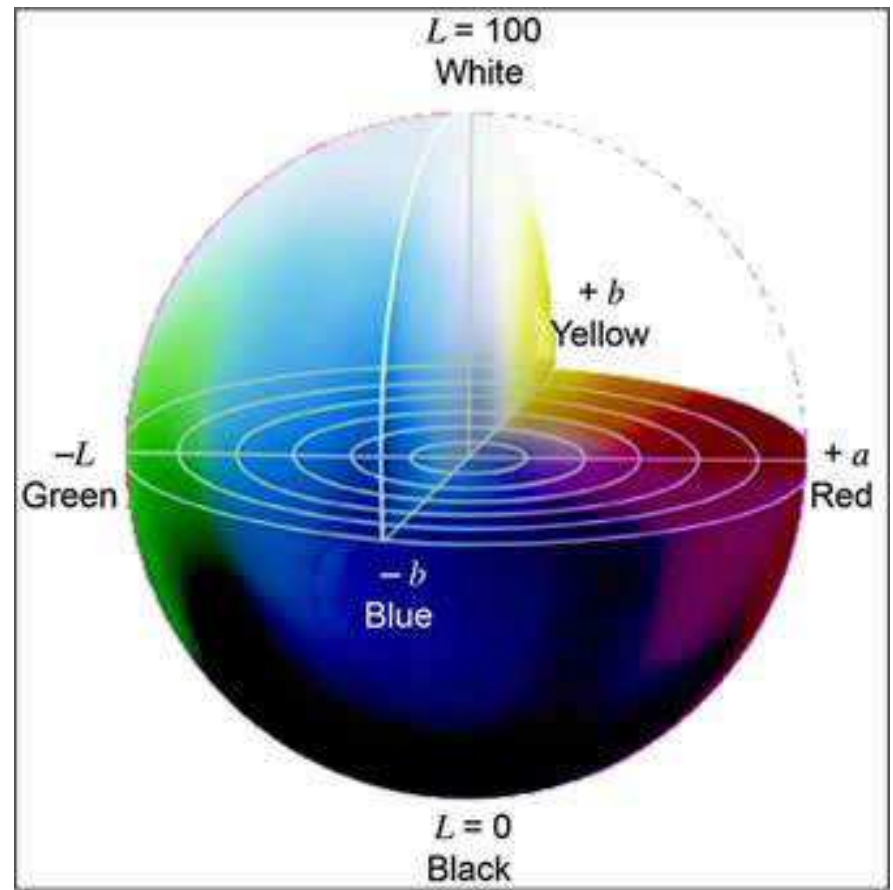

Fig. 4. Representation of a solid color in the space color $L^{*} a^{*} b^{*}$ (Konica Minolta, 2011) 
yellow $\left(+b^{*}\right)$ to the blue $\left(-b^{*}\right)$. The value $L$ determine the light ranging from white $(L=100)$ to black $(\mathrm{L}=0)$. The chroma is the ratio between $\mathrm{a}^{*}$ and $\mathrm{b}^{*}$, where the real color can be obtained. Hue-Angle is the angle between $a^{*}$ and $b^{*}$, indicating the color saturation of the analyzed object.

To estimate chroma value, the following formula was adopted (1) and to estimate the HueAngle, formula (2) (Estevez \& Cava, 2004).

$$
\begin{gathered}
\mathrm{C}=\sqrt{ }(\mathrm{a} 2+\mathrm{b} 2) \\
\mathrm{H}^{\mathrm{o}}=\operatorname{arcpg} \mathrm{b}^{*} / \mathrm{a}^{*}
\end{gathered}
$$

\subsection{Sensorial analyses}

Sensory acceptances of the irradiated and non-irradiated kiwi nectar were done with 41 non-expert panelists.

It was requested the participation of healthy adults (from 18 to 50 years old) of both sexes who declared kiwi's consumers and, that did not present any reaction concerning the consumption of the same and the same ones manifested its consent. They were selected by aleatoric base. The sensorial analysis was constituted by color; smell; flavor; texture and overall acceptance.

Panelists were instructed to evaluate each attribute using a nine-point hedonic scale ranging from "extremely dislike" to "extremely like". Test of acceptability of hedonic scale was used, since it is necessary to know the consumers "affectionate status" regarding the product inferring the preference, in other words, the most favorite samples are the more accepted and vice versa. The scales were balanced once they present equal number of positive and negative categories (1 to 9) (Ferreira, 2000).

About $50 \mathrm{ml}$ of each kiwi nectar treatment were given individually to the panelists and a three digit code was used for the sample. Mineral water was provided to wash the oral cavity after tasting each treatment

To red light was used to mask possible induction by the color in others attributes (Ferreira, 2000).

\subsection{Statistical analyses}

The experimental design was complete randomized with three replications. Results were analyzed (ANOVA) using the F test, and mean comparisons were tested based on Tukey $(\mathrm{p}<0,05)$ using SAS (Statistical Analysis System, 1996).

\section{Results and discussion}

\subsection{Tenor of soluble solids}

The obtained variations of Brix (Brix degrees) of the kiwi nectar irradiated at doses of: 0 (control); 0.5; 1.0; $2.0 \mathrm{kGy}$ are in Table 1.

Is possible to observe in agreement with the Table 1 , that the treatment which received radiation dose of $2.0 \mathrm{kGy}$ presented a larger amount of soluble solids, following by dose of 
$0.5 \mathrm{kGy}$. For the control the nectar irradiated at $1.0 \mathrm{kGy}$ was found the same amount of soluble solids, in other words, the same value for ${ }^{\circ}$ Brix.

\begin{tabular}{|c|c|c|c|c|}
\hline Dose & ${ }^{\circ}$ Brix & $\begin{array}{c}\text { Acidity titled } \\
(\%)\end{array}$ & $p H$ & Ascorbic acid \\
\hline Control & $16.70 \pm 0.01^{\mathrm{b} 2}$ & $8.8 \pm 0.11^{\mathrm{b}}$ & $3.5 \pm 0.1^{\mathrm{b}}$ & $108.0 \pm 0.01^{\mathrm{a}}$ \\
\hline 0.5 & $16.60 \pm 0.01^{\mathrm{c}}$ & $9.2 \pm 0.1^{\mathrm{a}}$ & $3.2 \pm 0.1^{\mathrm{a}}$ & $108.0 \pm 0.01^{\mathrm{a}}$ \\
\hline 1.0 & $16.70 \pm 0.01^{\mathrm{b}}$ & $8.2 \pm 0.1^{\mathrm{c}}$ & $3.0 \pm 0.1^{\mathrm{c}}$ & $54.0 \pm 0.01^{\mathrm{b}}$ \\
\hline 2.0 & $16.80 \pm 0.01^{\mathrm{a}}$ & $8.8 \pm 0.1^{\mathrm{b}}$ & $3.0 \pm 0.1^{\mathrm{d}}$ & $54.0 \pm 0.01^{\mathrm{b}}$ \\
\hline
\end{tabular}

${ }^{1}$ Media \pm Standard Deviation

${ }^{2}$ medias with different word(s) in the vertical they differ significantly at the level of $5 \%$.

Table 1. Variation of Brix (degrees Brix), acidity titled, $\mathrm{pH}$ and ascorbic acid of the kiwi nectar irradiated to $0.5 ; 1.0 ; 2.0 \mathrm{kGy}$ and, in the control

Statistical differences were verified among the treatments, indicating that the irradiation influenced this parameter, confirmed in a study accomplished by Spoto and VerunaBernardi (2002) in orange juice irradiated in several doses an increase was observed in the tenor of soluble solids.

In the research they found values above the literature for fruit the kiwi nectar needs sucrose addition to reach to $15{ }^{\circ}$ Brix (ideal to nectar) what allowed an ideal palate for the consumption in terms of sugar percentage

\subsection{Titled acidity}

The obtained variations of the titled acidity ( $\%$ of citric acid) of the kiwi nectar irradiated at doses of: 0 (control); 0.5; 1.0; $2.0 \mathrm{kGy}$, are in Table 1.

Is possible to observed through of the Table 1 , that the dose of $(0.5 \mathrm{kGy})$ which received the smallest radiation presented an increase in the acidity tenor indicating that the treatment influenced for the increase following by the control that did not differ statistically of the doses of $2.0 \mathrm{kGy}$ and $1.0 \mathrm{kGy}$ presented a smaller acidity among the analyzed samples.

The tenors of total acids vary from $1.0-1.5 \%$ being the citric acid the principal. In this work were found values above the one of the literature for kiwi.

Study accomplished by Leite; Gêa; Arthur; 2006, showed tenors of total acids for the sample non- irradiated $16.04 \%$, and for the sample irradiated 16.58 and $15.85 \%$ for the doses of 1.0 and $2.0 \mathrm{kGy}$, respectively.

These values differ to the values found in this work; what could be explained by the degree of fruit maturation. 


\section{$3.3 \mathrm{pH}$}

The obtained variations of the $\mathrm{pH}$ of the kiwi nectar irradiated at doses of: 0 (control); 0.5; 1.0; $2.0 \mathrm{kGy}$ are in Table 1.

Is possible to observe that with the irradiation there was a decrease in the value of the $\mathrm{pH}$, what resulted in more acid nectar, as increased with the dose of gamma radiation.

In agreement with Matsumoto et al. (1983), the $\mathrm{pH}$ value for the kiwi nectar should be around of 3.3. However, the sample that more approached this research was submitted to the irradiation with dose of $0.5 \mathrm{kGy}$.

Study accomplished by Leite; Gêa; Arthur; 2006 showed values of pH 3.38 for the samples irradiated in the doses of 1.0 and $2.0 \mathrm{kGy}$, and 3.41 for the sample no- irradiated. These values are same to the values found for in this research.

\subsection{Total ascorbic acid}

The results of total tenor of ascorbic acid (nectar $\mathrm{mg} / 100 \mathrm{~mL}$ ) of the kiwi nectar irradiated at doses of: 0 (control); 0.5; 1.0; $2.0 \mathrm{kGy}$ are in Table 1.

With relation the total tenor of ascorbic acid presents (Table 1), is noticed that the irradiation in the doses of 1.0 and $2.0 \mathrm{kGy}$ promoted a reduction of $50 \%$ regarding the control and the samples irradiated with dose of $0.5 \mathrm{kGy}$.

\subsection{Color analysis}

According to Table 2, the treatment does not promote significant alterations in the color parameters.

\begin{tabular}{|c|c|c|c|c|c|}
\hline Dose & \multicolumn{5}{|c|}{ Parameters } \\
\hline & $\mathrm{L}$ & $\mathrm{a}^{*}$ & $\mathrm{~b}^{*}$ & Croma & Hue-Angle \\
\hline Control & $22.03 \pm 0,00^{1} \mathrm{a} 2$ & $-2.23 \pm 0.00^{\mathrm{a}}$ & $5.33 \pm 0.00^{\mathrm{a}}$ & 5.78 & -1.17 \\
\hline 0.5 & $23.20 \pm 0,00 \mathrm{a}$ & $-2.05 \pm 0.00^{\mathrm{a}}$ & $4.95 \pm 0.00^{\mathrm{a}}$ & 5.36 & -1.18 \\
\hline 1.0 & $23.68 \pm 0,00 \mathrm{a}$ & $-2.19 \pm 0.00^{\mathrm{a}}$ & $5.40 \pm 0.00^{\mathrm{a}}$ & 4.91 & -1.11 \\
\hline 2.0 & $22.23 \pm 0,00 \mathrm{a}$ & $-1.76 \pm 0.00^{\mathrm{a}}$ & $4.47 \pm 0.00^{\mathrm{a}}$ & 4.80 & -1.20 \\
\hline
\end{tabular}

${ }^{1}$ Mean \pm Standard Deviation

${ }^{2}$ Means with different word(s) in the vertical differ significantly at the level of $5 \%$.

Table 2. Mediun Values of L, a*, b*, Croma e Hue-Angle of kiwi nectar 
There was not a lineal decrease in the treatments, but the treatments did not promote statistical differences between the samples. (Lee et al., 2008), in coherence with (Jo et al., 2003), present in their study a decrease of color values in their irradiation treatments for tamarind juice and fresh green tea, respectively. But (Kim et al., 2006) study, Curcuma aromatica extracts got an improvement in color by gamma radiation.

\subsection{Sensorial analysis}

For the sensorial analysis was not found difference in significant statistics among the aspects analyzed in the present study (color, aroma, flavor, texture and overall acceptance) for doses used, according to Table 3.

Those results are similar to (Lee at al., 2008) and they were in coherence with the previous studies of (Song et al., 2007), that did not had significant change observed in the irradiated tamarind juice and fresh vegetable juices, when compared with juices non-irradiated. Thus also maintains the sensory qualities of the kiwi nectar.

\begin{tabular}{|c|c|c|c|c|c|}
\hline \multirow{2}{*}{ Samples } & \multicolumn{5}{|c|}{ Parameters } \\
\hline & Color & Smell & Flavour & Texture & Acceptance \\
\hline Control & $6.19 \pm 1.92^{1} \mathrm{a} 2$ & $6.14 \pm 1.84^{\mathrm{a}}$ & $6.32 \pm 1.79^{\mathrm{a}}$ & $6.26 \pm 1.82^{\mathrm{a}}$ & $6.41 \pm 1.98^{\mathrm{a}}$ \\
\hline 0.5 & $5.68 \pm 1.93^{\mathrm{a}}$ & $5.44 \pm 1.93^{\mathrm{a}}$ & $5.76 \pm 1.82^{\mathrm{a}}$ & $5.78 \pm 1.71^{\mathrm{a}}$ & $5.75 \pm 1.92^{\mathrm{a}}$ \\
\hline 1.0 & $5.48 \pm 2.10^{\mathrm{a}}$ & $5.88 \pm 2.33^{\mathrm{a}}$ & $6.29 \pm 1.69^{\mathrm{a}}$ & $6.22 \pm 1.95^{\mathrm{a}}$ & $5.95 \pm 1.80^{\mathrm{a}}$ \\
\hline 2.0 & $5.24 \pm 1.92^{\mathrm{a}}$ & $5.60 \pm 2.18^{\mathrm{a}}$ & $5.43 \pm 1.56^{\mathrm{a}}$ & $5.95 \pm 1.95^{\mathrm{a}}$ & $5.51 \pm 1.78^{\mathrm{a}}$ \\
\hline
\end{tabular}

${ }^{1}$ Mean \pm Standard Deviation

${ }^{2}$ Means with different capital word(s) in the vertical differ significantly at the level of $5 \%$.

Table 3. Sensorial Analisys about color, smell, flavor, texture and acceptance.

All results are according to Harder et al. (2009) that found the same data for these parameters.

\section{Conclusion}

The results show that gamma radiation when used as a process of treatment for kiwi nectar did not promote significant alterations in the physiochemical and sensorial characteristics of the kiwi nectar, with exception for total ascorbic acid in the doses of 1.0 and $2.0 \mathrm{kGy}$. Then the process of irradiation can used to conserved kiwi nectar, because the gamma radiation has no negative influence in characteristics of the kiwi nectar. 


\section{References}

Almeida, J. R. Kiwi - Cultura de Actinídeas: como Produzir, como Vender. Clássica Editora. Lisboa, mar. 1996.

AOAC, Official methods of analysis of AOAC international, AOAC, Gaithersburg, USA. 2005.

Bible, B.B.; Singha, S. Canopy position influences cielab coordinates of peach color. Hortscience, 28, p. 992-993, 1997.

Carvalho, A. V., Lima, L. C. O. Qualidade de kiwi minimamente processados e submetidos a tratamentos com ácido ascórbico, ácido cítrico e cloreto de cálcio. Pesquisa Agropecuária Brasileira, 37, p. 679-685, 2002.

CEAGESP. Kiwi. In: www.ceagesp.gov.br.

Chang, C.C.; Lin Y.T.; Lu, Y.T.; Liu, Y.S. Kiwi improves bowel function in patients with irritable bowel syndrome with constipation. Asia Pacific Journal of Clinic Nutrition, 19, p. 451-457, 2010.

Demczuk Junior, B. Influência de pré-tratamentos químicos nas características físicoquímicas e sensoriais do kiwi submetido à desidratação osmótica e armazenado sob refrigeração. 2007. Dissertação (Mestrado em Tecnologia em Alimentos) Universidade Federal do Paraná, Curitiba.

Embrarad. http://www.embrarad.com.br ., (2007).

Estevez, M.; Cava, R. Lipid and protein oxidation, release of iron from heme molecule and colour deterioration during refrigerated storage of liver pate. Meat Science, 68, p. 551-558, 2004.

Ferreira, L. P. Análise sensorial: testes discriminativos e afetivos, SBCTA, Campinas, Brasil,185p., 2000.

Ferri, V. C.; Kersten, E.; Machado, A. A. Efeito do ácido indolbutírico no enraizamento de estacas semilenhosas de kiwi (Actinidia deliciosa, A. Chev.) cultivar Hayward. Revista Brasileira de Agrociência, v. 2, n. 1, p.63-66, jan.-abr. 1996.

Harder, M. N. C.; Toledo, T. C. F.; Ferreira, A. C. P.; Arthur, V. Determination of changes induced by gamma radiation in nectar of kiwi fruit (Actinidia deliciosa). Radiation Physics and Chemistry, 78, p. 579-582, 2009.

Jacobs, M. B. The chemical analysis of foods and food products, Van Nostrand, New York, USA. 356p. 1985.

Jo, C.; Son, J.H.; Lee, H.j.; Byun, M.W. Irradiation application for color renoval and purification of green tea leaves extract. Radiation Physics Chemistry, 66, p. 179-184, 2003.

Kim, J.K.; Jo, C.; Hwang, H.J.; Park, H.J.; Kim, Y.J.; Byun, M.W. (2006) Color improvement by irradiation of Curcuma aromatica extract for industrial application. Radiation Physics Chemistry, 75, p. 449-452, 2006.

KONICA MINOLTA. Comunicação precisa da cor. Controle de qualidade da percepção à instrumentação. Japan, 2001.

Lee, J.W.; Kim, J.K.; Periasamy, S.; Jong-il, C.; Kim, J.H.; Han, S.B.; Kim, D.J.; Byun, M.W. Effect of gamma irradiation on microbial analysis, antioxidant activity, sugar content and color of ready-to-use tamarind juice during storage. Food Science and Tecnology, 42, p. 101-105, 2008. 
Leite, D.T.S.; Gêa, A.S.; Arthur, V. Efeito de diferentes doses de radiação nas características físico-químicas de kiwi minimamente processado. In: http://www.cena.usp.br/ecpg/trabalhos/16.PDF. , 2006.

Levit, V.; Santos, A. da S. dos; Foes, A. D. R., Preservação de pêssegos por irradiação. In: REUNIÃO ANUAL DA SOCIEDADE BRASILEIRA DE QUÍMICA, 31., 2008, Águas de Lindóia, Anais eletrônicos da Sociedade Brasileira de Química. Águas de Lindóia, 2008. Disponível em:

<http://www.sbq.org.br/ranteriores/23/resumos/1174-2/index.html>.

Acesso em: 18 abr. 2011.

Lopes, M.S; Lopes, N.E.C.; Gomes, E.R.S; Pereira, N.C. . Análise de minerais no suco de acerola ultrafiltrado e concentrado por osmose inversa. IV Congresso Brasileiro de Engenharia Química e Iniciação Científica. 6 p., 2005.

Matsumoto, S. T., Obara, B., Luh, S. Changes in chemical constituents of kiwifruit during postharvest ripening., Journal of Food Science, 48, p. 607-611, 1983.

Modolo, D. M.; Silva, L. C. A. S.; Arthur, V. Irradiação de frutos de kiwi (Actinidia deliciosa). Simpósio Internacional de Iniciação Cientifica da Universidade de São Paulo. Piracicaba, Resumo, pg. 189., 2011.

Oliveira, A. C. S. Avaliação dos efeitos da radiação gama nas características físico-químicas de kiwi (Actinídia deliciosa, A. Chev. ) cv. Hayward minimamente processado. 2011. Dissertação (Mestrado em Tecnologia Aplicada) - Instituto de Pesquisas Energéticas e Nucleares - IPEN, São Paulo.

Oliveira, A. C. S.; Silva, L. C. A.; Oliveira, M.; Modolo, D.; Arthur, V. Evaluation of gamma radiation on minimally processed kiwifruit. International Meeting on Radiation Processing. Montreal, Abstract, p.189, 2011.

Ornellas, C. B. D.; Gonçalves, M. P. J.; Silva, P. R., Martins, R. T. Atitude do consumidor frente à irradiação de alimentos. Ciência e Tecnologia de Alimentos, v.26, n.1, p. 211213, jan.-mar., 2006.

Schuck, E., (1992). Cultivares de quiwi., Agropecuária Catarinense, 5, p. 9-12. Ano

SEMAPI. Sistema de produção de kiwi tutorado. In: http://sustentabilidadesemapi.blogspot.com/2009_01_01_archive.html.

Song, H.P.; Byun, M.W.; Jô, C.; Lee, C.H.; Kim, K.S.; Kim, D.H. (2007) Effects of gamma irradiation on the microbiological, nutritional, and sensory properties of fresh vegetable juice. Food Control, 18, p. 5-10. Ano

Souza, P. V. D.; Marodin, G. A. B.; Barradas, C. I. N. Cultura do quivi. Porto Alegre, RS : Cinco Continentes, 1996.

Spoto, M. H. F., Verruma-Benardi, M. R.. Estudo microbiológico e físico-químico do suco de laranja fresco irradiado., Higiene Alimentar, 16, p. 76-80, 2002

Statistical Analysis System Institute,). Sas/Qc. Software: usage and reference, Statpoint, Inc., Herndon, USA, 1996.

Tocchini, R. P.). Industrialização de polpas, sucos e néctar de frutas, Ital, Campinas, Brasil, 167p., 1995.

USDA. Kiwi world production and exports. In: www.ers.usda.gov/data/fruitvegphyto/Data/fr-kiwi.xls. 
Villavicencio, A. L. C. H., Manzini-Filho, J., Delincée, H. Application of different techniques to identify the effect of irradiation on Brazilian beans after six months storage., Radiation Physics and Chemistry, 52, p. 161-166, 1998.

Wiendl, F. M. Irradiação de alimentos. Biológico, v 59, n.1, p. 75-76, 1997. 


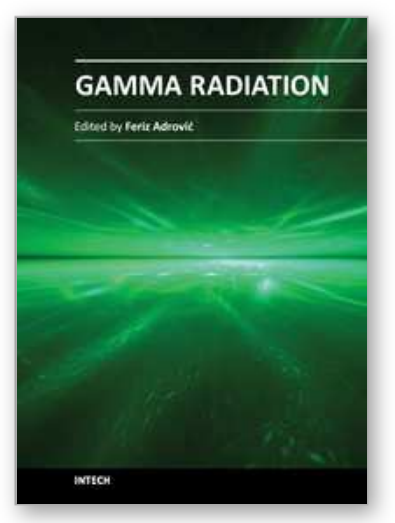

\author{
Gamma Radiation \\ Edited by Prof. Feriz Adrovic
}

ISBN 978-953-51-0316-5

Hard cover, 320 pages

Publisher InTech

Published online 21, March, 2012

Published in print edition March, 2012

This book brings new research insights on the properties and behavior of gamma radiation, studies from a wide range of options of gamma radiation applications in Nuclear Physics, industrial processes, Environmental Science, Radiation Biology, Radiation Chemistry, Agriculture and Forestry, sterilization, food industry, as well as the review of both advantages and problems that are present in these applications. The book is primarily intended for scientific workers who have contacts with gamma radiation, such as staff working in nuclear power plants, manufacturing industries and civil engineers, medical equipment manufacturers, oncologists, radiation therapists, dental professionals, universities and the military, as well as those who intend to enter the world of applications and problems of gamma radiation. Because of the global importance of gamma radiation, the content of this book will be interesting for the wider audience as well.

\title{
How to reference
}

In order to correctly reference this scholarly work, feel free to copy and paste the following:

Marcia N. C. Harder and Valter Arthur (2012). The Effects of Gamma Radiation in Nectar of Kiwifruit (Actinidia deliciosa), Gamma Radiation, Prof. Feriz Adrovic (Ed.), ISBN: 978-953-51-0316-5, InTech, Available from: http://www.intechopen.com/books/gamma-radiation/the-effects-of-gamma-radiation-in-nectar-of-kiwifruitactinidia-deliciosa-

\section{INTECH}

open science | open minds

\author{
InTech Europe \\ University Campus STeP Ri \\ Slavka Krautzeka 83/A \\ 51000 Rijeka, Croatia \\ Phone: +385 (51) 770447 \\ Fax: +385 (51) 686166 \\ www.intechopen.com
}

\author{
InTech China \\ Unit 405, Office Block, Hotel Equatorial Shanghai \\ No.65, Yan An Road (West), Shanghai, 200040, China \\ 中国上海市延安西路65号上海国际贵都大饭店办公楼405单元 \\ Phone: +86-21-62489820 \\ Fax: $+86-21-62489821$
}


(C) 2012 The Author(s). Licensee IntechOpen. This is an open access article distributed under the terms of the Creative Commons Attribution 3.0 License, which permits unrestricted use, distribution, and reproduction in any medium, provided the original work is properly cited. 